\title{
From Babylonia to Bombay to Burma: Sojourning through Asian Hebraica by Way of New York
}

THIS WINTER PAST, I journeyed to Sotheby's to bear witness to a wonder: the hallowed holdings of the Valmadonna Trust Library (VTL) collection on exhibit in New York. I ventured forth to explore this rarefied repository of tenth- through early twentieth-century ${ }^{1} \mathrm{CE}$ texts, declared by the cognoscenti to be "the finest private library of Hebrew books and manuscripts in the world."2 As I joined the caravan of inquiring minds and devout adherents alike in a lengthy line that extended around the corner from the auction house's York Avenue entrance, the hour-long wait allowed me time to cross-match the gallery floor layout copy (readily proffered by Sotheby's staff to the February frost-defying, slightly shivering crowd of bibliophiliacs) with my notes and a map of Hebrew printing presses ${ }^{3}$ to devise a logistical plan of approach for viewing le grande corpus - with specific intent to probe its Indian and Chinese acquisitions. ${ }^{4}$ The framing of a panoramic view-captured against the fluidly complex backdrop of historic regions of Asia Minor, the Levant, Mesopotamia (modern Iraq, Syria, Turkey, Iran), Transcaucasia, Greater India, Greater Persia, Eurasia, and the Pacific Rim - is presented throughout this review to bring into fuller focus the significance of the sphere and scope, the reach and range of the Asian Hebraic components within VTL's larger Judaica collection.

Besotted and bemused was I upon exiting the elevator of the tenth floor galleries. Five adjoining rooms were devoted to the display of more than 11,000 manuscripts, monographs, scrolls, single leaves, entire series, folios, chapbooks, broadsheets, wall calendars, incunabula, codices, periodicals, ephemera, lithographic prints, and

1. All dates noted are understood throughout as Gregorian solar, civil calendar reckoning. The author disavows herself of any religious presumptions or political persuasions that some readers may attach to this article. She claims none in this writing; none should be assumed.

2. Edward Rothstein, "A Lifetime's Collection of Texts in Hebrew, at Sotheby's," New York Times, February 11, 2009, Books section, online edition. Available online at www.nytimes.com/2009/02/12/ books/12hebr.html. [Accessed 8 September 2009].

3. Martin Gilbert and Arthur Banks, Jewish History Atlas (New York: Macmillan Publishing Co., 1969).

4. Sotheby's, The Valmadonna Trust Library (New York: Sotheby’s, 2009). Available online at www. sothebys.com/liveauctions/event/valmadonnaTrustLibraryBrochure.pdf. [Accessed 8 September 2009]. 
woodcut relief illustrations - with a separate alcove designated solely to volumes of the Talmud [Oral Law]. In a sixth sitting room situated near the reception area, a continuously looped 24-minute video presentation streamed collector Jack V. Lunzer's recollections of his 25-year-long quest to obtain King Henry VIII's copy of the Talmud owned by the Westminster Abbey.

Comprising works both religious (Tanakh and Masoretic texts, Torahs, Talmuds, Kabbalah esoterica, prayerbooks, liturgies, Passover Haggadot [ritual Seder feast guides]) and secular (law, science, medicine, philosophy, prose, grammar, linguistics, travel, geographic exploration, rhetoric), the VTL collection is a tour de force of monumental importance described by its custodian Lunzer as a "rescue operation." 5 Amassed over six decades (under the librarianship of Pauline Malkiel and chief bibliographic advisement of Professor Chimen Abramsky) from an initial trove of sixteenth-century CE Italian Hebraica from his wife Ruth's father, Lunzer's magnificent collection was augmented with acquisitions from auctions, other legendary collectors such as David Solomon Sassoon and Salman Schocken, directly negotiated purchases, and a Charter/endowment exchange with the Abbey's capital restoration fund.

The ambient palpability of these works accompanied me as I sauntered through the main gallery-a library encompassing 222 square metres of floor-to-ceiling, name-plated, bookshelved space, with ten rows running full length per walland no room for canopy. Delineated not by subject matter but by provenance, I first encountered the Italian collection, lingering longer than anticipated among fifteenth-century CE cradle-books in the splendid Venice section. Privileged was I to view works from the earliest mechanized printing presses of this region: the editio princeps of Nahmanides' Perush al ha-Torah (Commentary on the Torah)—a signed imprint from the workshop of Obadiah, Manasseh, and Benjamin of Rome, a ca. 1469 CE production; and Moses Maimonides' Mishnah Torah (Repetition of the Torah)—printed in Naples in 1492 CE. I surveyed segments of many gloriously gilded works from Trieste, Livorno, Pisa, Verona, Milan, Florence, Naples, Riva di Trento, Cremona, Mantua, Venice, Sabbionetta, Rome, and Rimini.

Movable type was introduced to the region just months after the fall of Constantinople to the Ottoman Empire (April $1453 \mathrm{CE}$ ), from which Byzantine scholars streamed into Italy. The VTL collection aggregates Hebrew treasures of that era, in confluence with that of later Sephardic Jewish expulsions, according to Lunzer's selective interests. On my way toward the Asian quad, I tarried before a mix of

5. Sotheby's, Private View (New York, New York: Sotheby's, 2009), slideshow. Available online at www.sothebys.com/video/movies/index_valmadonna.html. [Accessed 8 September 2009]. 


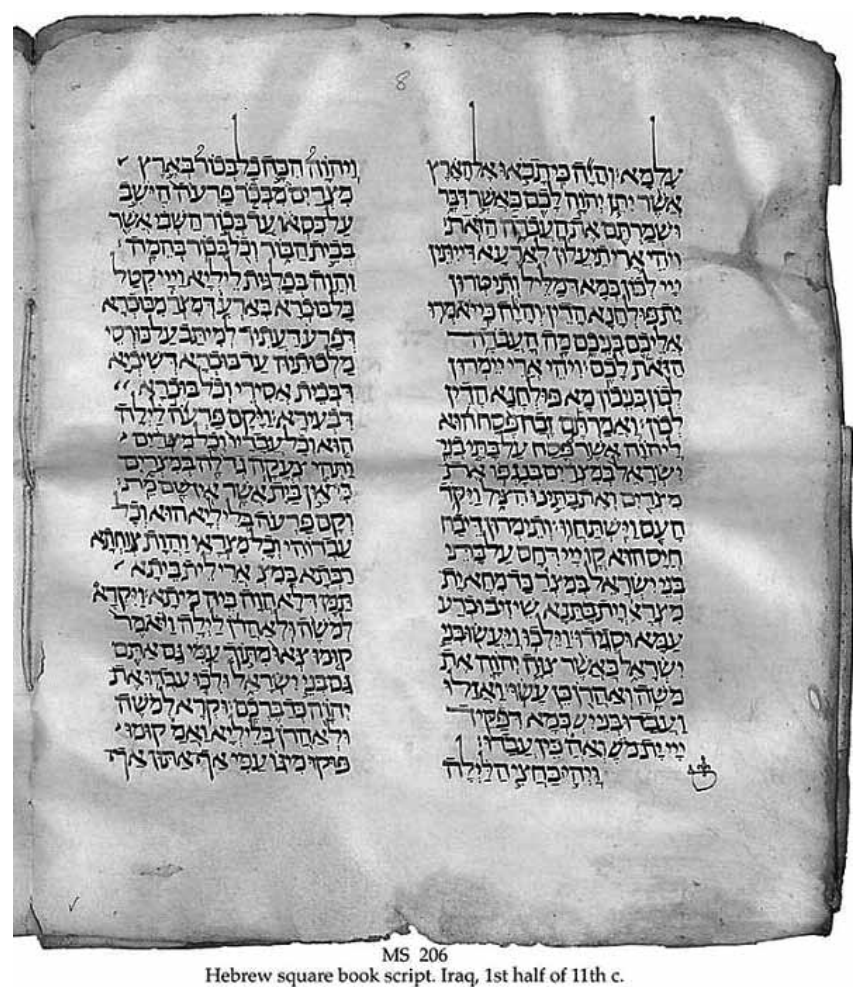

Image 1. Targum Onqelos from a Kurdistan Genizah, Iraq, eleventh century CE. Hebrew and Aramaic translation of Book of Exodus on vellum. The Schøyen Collection MS 206, Oslo and London. Courtesy of Martin Schøyen.

manuscripts of immeasurable worth from Aden, Aleppo, Alexandria, Amsterdam, Baghdad, Barcelona, Bologna, Cairo, Cologne, Constantinople, Corfu, Ferrara, Fez, Geneva, Izmur [Smyrna], Jerusalem, Leiden, Paris, Prague, Safed, Thessaloniki, and Vienna before reaching the Indian works, working clockwise while cross-referencing my maps and shelf labels. Books from Poona and Cochin were difficult for me to get near enough to view well, located as they were on the second-from-bottom shelves, near floor level. (Patrons were separated from the stacks by cordons of string and a squadron of auction house guardsmen.) VTL's Calcutta and Shanghai possessions were higher up, and I was able to read the spines. Only the ineffable "Wow!" can describe the truly memorable moments standing so closely to these books, studying their well-preserved spines - their secrets bound by leather and silence of the ages, and me separated from them by more than cords.

Annals of the Books of Kings convey that upon Solomon's death, the United Monarchy of the Kingdom of Israel was bifurcated (ca. 928 BCE) into the Northern Kingdom of Israel and the Southern Kingdom of Judah. The Tanakh (Hebrew 
Bible) further chronicles ${ }^{6}$ the conquest and annexation of Samaria (ca.729-722 BCE) by Neo-Assyrian monarchs and subsequent deportation of those Northern Kingdom captives to distant regions of Greater Mesopotamia (southwestern Iran, Iraq, northeastern Syria, and southeastern Turkey) and Greater Khorasan (modern Afghanistan, Iran, Tajikistan, Turkmenistan, and Uzbekistan), to which the Christian New Testament attests. ${ }^{7}$

En suite, the Neo-Babylonian/Chaldaean defeat of the Southern Kingdom of Judah, captivity of its population, destruction of Solomon's Temple, final demise of the House of David, misappropriation of treasures of Jerusalem, and transfer of the Judahite army, citizenry, nobility, and craftsmen to Babylonia occurred ca. 597-586 BCE. As a result, the Jews underwent three series of forced migrations between $740 \mathrm{BCE}$ and $586 \mathrm{BCE}$. Those Israelites who remained ${ }^{8}$ later fled to Egypt and were settled on the Sinai frontier (270 BCE), where (according to the Elephantine Papyri, a collection of 5 th-century BCE Hebrew manuscripts) a garrison of Jewish soldiers had been stationed earlier (ca. 650 BCE) during the initial Achaemenid Persian occupation of Egypt.

The Babylonian Empire-overthrown by and absorbed into the Persian Empire-culminated in a Persian Babylonia that effectuated the return to Palestine of Southern Kingdom Jews ca. 541-537 BCE. (Not all repatriated in 541 BCE; scions from among this remaining strand of the Babylonian Jewry joined the Bukharim ${ }^{9}$ of Central Asia in the eleventh century CE). It was from among this displaced population of formerly elite exiles (exilarchs) dispersed to the mountains of Medea, Nineveh, Halah, Habor (near Gozan River), and Babylonia (lower Mesopotamia, Iraq) that the Talmudic Academies of Sura, Pumbedhita, Mahuza, and Nehardea emerged and by whom the comprehensive, authoritative Talmud Bavli (Babylonian Talmud) was compiled. ${ }^{10}$

Showcased among the crown jewels of the Sotheby's galleries was the prime-condition, Oxford blind-paneled, calf-bound, nine-volume Bomberg Talmud set, which is the first complete printed edition (Venice, 1519/20-1523) of the Babylonian Talmud produced by the printing press of Daniel van Bomberghen.

\footnotetext{
6. 2 Rois 17:1-6, 2 Rois 18: 7-13 (La Bible de Jérusalem)

7. Acts 2:5-11. Peshitta Aramaic/English Interlinear New Testament. Available online at http:// www.peshitta.org/. [Accessed 7 September 2009].

8. Regum IV 25: 1-26. Vulgata Clementina. Available online at http://vulsearch.sourceforge.net/ $\mathrm{html} /$. [Accessed 7 September 2009].

9. Gilbert and Banks, Jewish History Atlas, 9; Nathan Ausubel, Pictorial History of the Jewish People: from Bible Times to Our Own Day (New York: Crown Publishers, 1953), 220.

10. Gilbert and Banks, Jewish History Atlas, 7.
} 
From among the erudite Babylonian Jewry came forth the Baghdadi Jews ${ }^{11}$ (of Iraqi, Iranian, Afghani, Yemeni, Syrian, Persian, Turkish origins). Among these were late sixth-century BCE traders active in the Persian capital city of Susa, the gateway to India. Their eighteenthcentury CE descendants arrived in the Sindh province of Surat in India, later advancing their tea, textiles, and opium trade networks farther eastward to ports in Burma, Singapore, Malaysia, China, and Japan.

Those of the Babylonian Jewry who migrated during the British Raj (1857-1947 CE), merging with their predecessors, are included in the appellation Baghdadi Jewry.

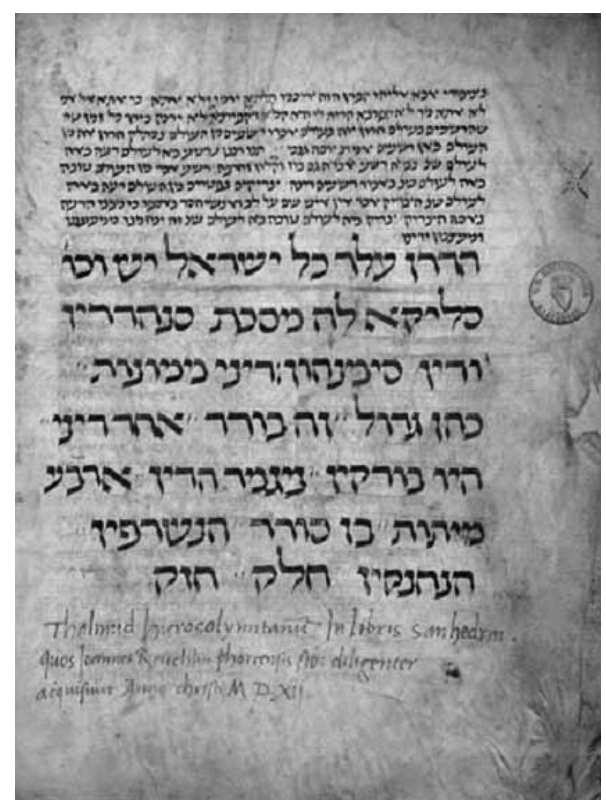

Image 2. Talmud Bavli (Babylonian Talmud), Tractate Sanhedrin, ca 1400-1450 CE. Codex Reuchlin 2, fol. 96v, Badische Landesbibliothek Karlsruhe. Image source: Wikimedia

The VTL is in possession of prime presswork representative of the Baghdadi printing houses that produced works of halakhic (Jewish religious law), literary, and liturgical content. Included in this subdivision from Bombay, Calcutta, Poona, and Cochin are broadsheets for Order of Service at the Magen David Synagogue; famine prayers; Blessing of the Sun booklets in Marathi language; a letter in Malabari dialect; a Haggadah lithograph in Hebrew, Judæo-Arabic, and Aramaic; Ecclesiastes in JudæoArabic; Benedictions according to the Baghdadi Rite; a lithographed lexicon in Hebrew, Hindustani, Persian, Arabic, and English; a Song of Songs lithograph in Aramaic and Judaeo-Arabic; 108 pages of propitiatory prayers and remission of vows in Hebrew and Aramaic;

11. Ausubel, Pictorial History of the Jewish People, 218. 
a Hebrew-Marathi account of the death of Moses; esoterica of Zohar translated from Aramaic Chaldæan into Arabic; and a Sephardic variation of Mahzor (High Holidays prayerbook). A Reading Room highlight for me was the mounted nineteenth-century CE Menorah lithographed blessing sheet. A most edifying find within the Manuscripts quarter was a 1929 CE Scroll of Esther (Megillat Ester). Kol Mevasser, Peirah, Maggid Mesharim, Shoshanah, and other periodicals were platforms of Hebrew, Judæo-Arabic, Marathi, English, and Yiddish journalism for the Oriental Diaspora. Eleven bound original issues of the Jewish Gazette (India's first Jewish newspaper) are among VTL's holdings. The early Baghdadis of India imported their prayer books and religious texts from Jerusalem, Italy, and the Dangoor printing house in Baghdad; these documents are inventoried as part of the (estimated) 40M\$ (US) Sotheby's private sale.

\section{The Malabar Yehudan (Cochinim) ${ }^{12}$}

were among initial dispersions of Jews into South India during the time of the United Monarchy and after its division. The Kochini of Kerala-originally of the Tribe of Manasseh-were intercontinental spice traders who first settled along the Malabar Coast of India (ca. 700 BCE, 562 $\mathrm{BCE})$. Thereafter, sometime between the beginnings of the Judæo-Roman rebellion (66 CE), the Roman legion's reconquest (70 CE), and Emperor Hadrian's razing of Jerusalem (135 CE), exiled Israelites arrived en masse from Palestine, disembarking in $72 \mathrm{CE}$ at the port of Cranganore, near Cochin. Yehudeans streamed (ca. 369-490 CE) into the Judaic principality, and inheritors of this privileged property remained until ca. 1524-1534, when segments of the population escaped from Cranganore

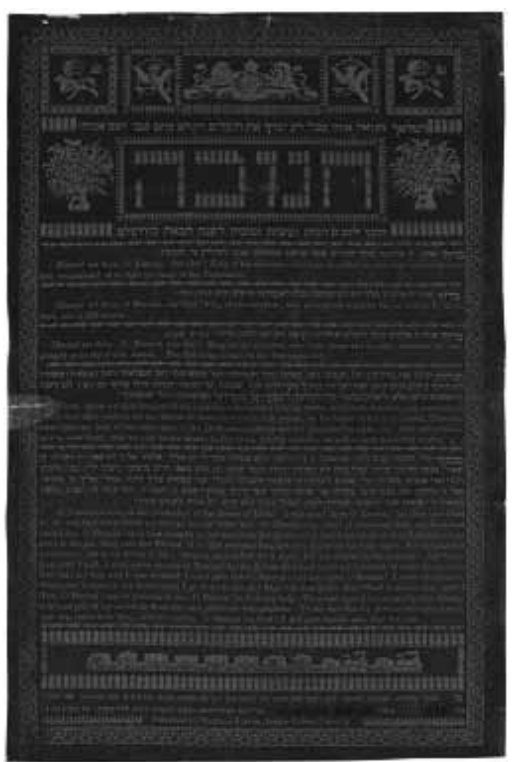

Image 4. Blessings on the Menorah, Calcutta. Late nineteenth century CE. Lithographed blessing sheet, gold ink on red paper. Valmadonna Trust Library, Courtesy of Sotheby's.

to seek sanctuary in Cochin during trade disputation with local Moors and from Portuguese subjugation. Living under subsequent Portuguese, Dutch, and British occupations, descendants of the original Malabar Yehudan (of the Indo-Iranian dislocation) made their way beyond Kerala to other states of India.

12. Gilbert and Banks, Jewish History Atlas, 12; Ausubel, Pictorial History of the Jewish People, 222-223; Barbara C. Johnson, "The Cochin Jews of Kerala," in The Jews of India: a Story of Three Communities, eds. Orpah Slapak and Muzeon Yisrael (Jerusalem: University Press of New England, 1995), 27-35. 


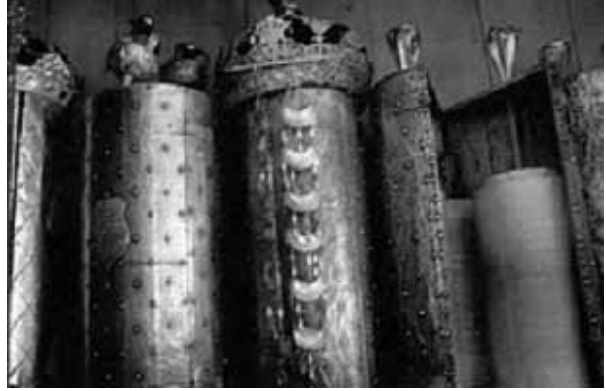

Image 5. Torah Scrolls, India, Cochini Synagogue. Image source: Stephanie Comfort. Used with permission.
There exists a Yehudan record called the Cochin History Roll that records events occurring among this strand of the Manasseh Tribe prior to arrival in India. The Roll accounts for two dispersions-Persia-Medea-China and another northward Eurasian movement - but such manuscript was not located by me within Sotheby's assemblage. The oldest written works of all Indian Jewry

were scribed by the Cochinim, but during the Portuguese Inquisition, with their bodies and books besieged and burnt, their properties and personals decimated, the earliest evidences of Cochinim existence were obliterated in 1663 CE [paradoxically, a Christian adaptation of a Hebrew biblical command]. ${ }^{13}$

During the succeeding Dutch occupation of India, Ezekiel Rahabi (a Cochini trader with interests in the sciences and maths) and his son David reprinted (by effort of the exceedingly enterprising Jewish Dutch community) many of the earlier destroyed documents. By arrangement of David Rahabi, scrolls of the Pentateuch, prayer books, and various rabbinical works were sent from Amsterdam to Cochin. Jewish Dutch traders were otherwise commercially active, not only in Cochin but throughout India, Ceylon, Sumatra, Java, Timor, and other pockets of the Dutch East Indies. Although a 1570 printing press had been set up in Ambazhabad, near Cochin, this earliest typographic endeavour was not sustained. Jesuit and Anglican missionary presses filled in the literary lacuna but practiced technological protectionism while calligraphic guilds with vested interests in maintaining their scribal arts impeded the development of the Cochin publishing industry. A Hebrew-Malayalam press was established by 1841 in southern India, but many works published by and for Cochinim were printed principally by Marranos ${ }^{14}$ in Amsterdam in the 1700s-1800s.

Among these: Notisias dos Judeos de Cochim by Mosseh Pereyra de Paiva (a Portuguese-language publication of Ury ha Levy, printed in Yiddish under the title Tsaytung oyz Indya, in Judæo-German as Zeitung aus Indien, and translated in Spanish in manuscript form as Relacion de las Noticias de los Judios de Cochim); Seder Tefilot (re-

13. Rabbi Avram Israel Reisner, "On the Exodus (and Genesis) of Shemot" (paper approved by the Rabbinical Assembly of the Committee on Jewish Law and Standards, New York, December 5, 2003). Available online at www.rabbinicalassembly.org/teshuvot/docs/20012004/Reisner\%20Shemot.pdf. [Accessed 8 September 2009].

14. Gilbert and Banks, Jewish History Atlas, 47. 
published as Chuppat Chattanim); a collection of liturgical poems according to the Cochini Rite, Seder Azharot; liturgy and text regarding the manumission of Cochini slaves; and Ohel Dawid by David Rahabi. Genre and linguistic variation (Hebrew, Aramaic, Judæo-Arabic, and Malayalam) characterize the Cochini subcollection: texts, Kabbalistic tracts, narrative diwans (religious poetry), Hagaddot expressed as Indo-Judaic art, leaves of piyyutim (Jewish liturgical poems) with MalayalamAramaic translations, a Malabari targum (translation), exam papers, license, and prayers pertaining to shechita (ritual slaughter in accordance with dietary law), ephemera relating to aliyah (emigration to Israel) of Cochinim, a Hagaddah of Pesah (Passover) printed in Hebrew, Aramaic, and Malayalam; and a Psalm 8 lithograph.

Two native Cochinim of Yemenite parentage (Eliezer ben Aaron Saadiah Arakie ha-Kohen and Solomon Sharabi) and the scholar Hakham Shlomo Abid Twena established themselves among the Baghdadi publishing industry in the Calcutta region. To engage in the Jewish scribal arts is considered a consecrated calling, and production of religious texts are guided by strict Talmudic Law to be fit for ritual use. Cochinim slaves - prohibited from reading or transcribing Torah scrolls or other religious writings - were forbidden to engage in Sofrut (the practice of scribal arts) as copyists, calligraphers, or compositors, although manumitted Jewish slaves could enter the craft as bookbinders.

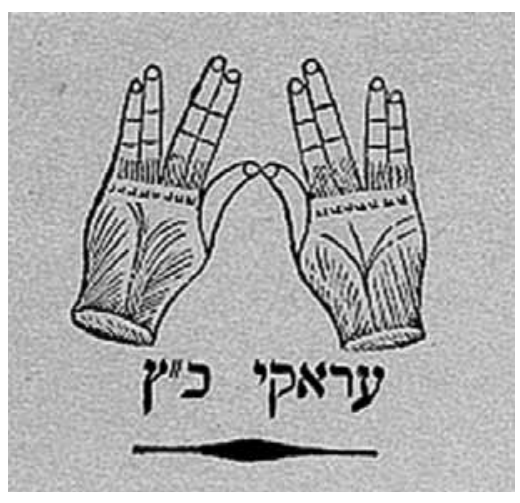

Image 6. Priestly Hands, Calcutta, 1844. Trademark of first Jewish printer in India, Cochini-born Eleazar b. Aaron Saadiah Iraqi (Arakie) ha-Kohen. Image source: Bibliothèque et Archives Canada. Used with permission.
The South Asian Bene Israel ${ }^{15}$ trace their heritage to regions of the inhospitable hills of northern Galilee and the pleasant plains of the Jezreel Valley from which they fled (ca. $280 \mathrm{BCE}-175 \mathrm{BCE}$ ) prior to the Maccabean émeute to escape an edict of Antiochus IV Epiphanes, who had outlawed Judaism and ordered the worship of Zeus as supreme god. This seafaring contingent of the Tribes ${ }^{16}$ of Zvulun and Asher was shipwrecked, stranded on the Konkan coast south of Bombay. They integrated throughout India, as well as that which is now Pakistan, Burma, and Yemen.

15. Ausubel, Pictorial History of the Jewish People, 221-222; Shirley B. Isenberg, "The Bene Israel," in The Jews of India: a Story of Three Communities, eds. Orpah Slapak and Muzeon Yisrael (Jerusalem: University Press of New England, 1995), 17-25.

16. Gilbert and Banks, Jewish History Atlas, 4. 
Deemed to be segments of what is known by the broad term Pakistani Jews, as Aaronites, these Bene Israel confirmedly hold claim to lineage of Moses' brother (as DNA tests have evidenced their Cohanim heredity). ${ }^{17}$ Having lost their Sefer Torah at sea, they continued their First Temple practices from memory, until scholars and hazanim (cantors) from Cochin, Baghdad, Yemen, and Syria were assigned many centuries later (commencing in the $1830 \mathrm{~s} \mathrm{CE}$ ) for observance according to halakhic law. This came about through Bene Israeli soldiers who, while fighting in the British Indian Army and stationed in the Aden port, formed a kinship alliance with the Yemenite Jews ${ }^{18}$ and, upon return, arranged for their transfer to serve in Indian synagogues.

The VTL holds in its trust HebrewMarathi translations prepared for the Bene Israeli: Books of Maccabees, a Rosh ha-Shanah (Jewish New Year) liturgy, Prayers of the Day of Atonement, Prayers of the Jewish New Year's Day, and The Jewish Propitiatory Prayer by the nineteenth-century CE leading scholar Joseph Ezekiel Rajpurker. Also on exposition was the Psalms of David in Marathi metre, Haggadah shel Pesach (Passover Seder) written in the Judæo-Marathi vernacular, translations of Relief of Vow according to Opinion of Beni-Israel and Praise after Monthly Appearance of the Moon, and a HebrewMarathi translation of Megilat Antiyokhus (Scroll of Antiokus, a recount of Hannukah and the Maccabees).

\section{$(1)$}

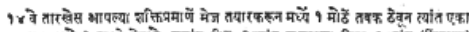

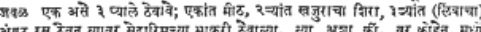

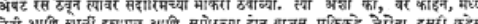

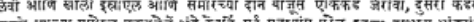

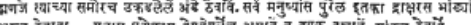

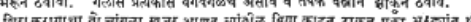

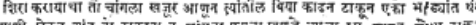

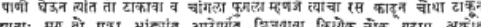

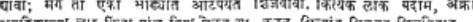

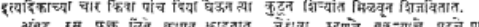

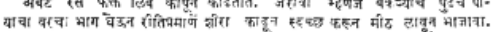
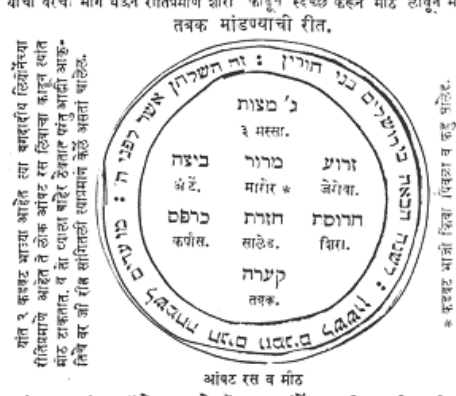

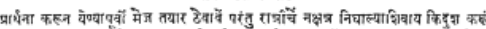

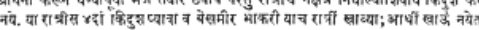

Image 7. Haggadah shel Pesah, Bombay, 1890. Judæo-Marathi transliterated print. Image source: Wikimedia.

Surviving the destruction of the Northern Kingdom, the children of ancient Samaria claim direct descent from the Joseph tribes, their ancestral extraction being that of Ephraim, Levi, and Manasseh. Genetic tests bear out the disputed ethnic claims of this branch of ancient Israelites who were not deported, ${ }^{19}$ who practice Samaritanism (related to, yet distinct from, mainstream rabbinical Judaism), consult the Samaritan Torah for authority, and whose sanctified site is Mount Gerizim-

17. Tudor Parfitt and Yulia Egorova, "Genetics, History, and Identity: the Case of the Bene Israel and the Lemba," Culture, Medicine, and Psychiatry 29 (2): 193-224.

18. Ausubel, Pictorial History of the Jewish People, 219-20.

19. Neil Asher Silberman and Israel Finkelstein, The Bible Unearthed: Archaeology's New Vision of Ancient Israel and the Origin of its Sacred Texts (New York: Free Press, 2002), 22-23, 297-99, 305-08. 
whereupon they built their Temple (ca. fifth- and sixth-century BCE). Like the Qara'im [Karaites], the Samaritans (Shomronim, Shamerim, "Observant Ones") believe themselves to be preservers of the most ancient forms of Israelite religion. Those who count themselves to be among the Samaritan progeny who did leave are India’s Bnai Menashe (Manipuri Jews). They profess that, enslaved and exiled by the Assyrians, some among the Bnai Menashe traversed-over an extended period of time-northeastward from Israel to Assyria to regions of Afghanistan. Alexander III of Macedon's Central Asian invasions of Parthia, Media, Afghanistan, and Tajikistan drove them farther on to Mongolia through Sino-Indian territories of Kashmir and Tibet, where they settled in the Chhinlungsan region of China. Later repatriating back to East India from Thailand, Laos, and Vietnam, they are now inhabitants of northeastern sister states of India (Manipur, Mizoram, Assam), Burma (Myanmar), and Bangladesh. Formerly residing on the Chinese/Burmese borders, these self-described Jewish Indo-Chinese are of the Chin, Kuki, and Mizo clans-known previously and collectively as the "Shinlung" (cave dwellers). DNA testing has, so far, not corroborated their claims. ${ }^{20}$

A representative work of this nearly extinct sect (with fewer than 800 residing in present-day West Bank [CisJordan] and a Tel Aviv suburb) was on display within the Manuscripts Room: a twelfth-century Samaritan Pentateuch scroll (written in the

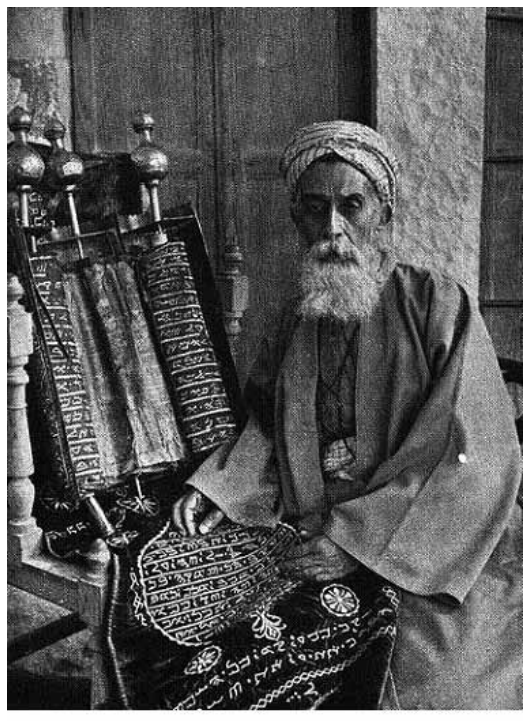

Image 8. High Priest of the Samaritans with Codex Nablus, Palestine. ca. 1920. Image source: Wikimedia. ancient Paleo-Hebrew variant of Phoenician, non-Aramaic script) containing a precept directing worshippers to make their pilgrimage to Mount Seir (Edom/ Judah) for Pesach observances.

The Yudulu of Andra Pradesh ${ }^{21}$ — said to be the offspring of Ephraim-reside in an isolated southeastern village near River Krishna, arriving from the northern regions of India, Afghanistan, and the North-Eastern Frontier in the ninth or tenth centuries CE. The Bene Ephraim (Jews of Guntur) adhere to the Hebrew lunisolar calendar, observing its High Holy Days celebrations. The congregation possesses no Torah scroll but, on Shabbat, reads parashiyyot (sections)

20. Rashmee Z. Ahmed, "India's Children of Israel Find their Roots," Times of India, July 20, 2002, World section, Delhi.

21. Ibid. 
from Hebrew-English bound-book editions of the Pentateuch (Chumash, Five Books of Moses) and recite blessings (berachot) in their Telugu language using transliterated Ashkenazi siddurim (prayer books). Their Hebraic studies materials are brought from Israel.

The Qnanaya (Qnai) Christians are ethnic Jews of Syro-Aramaic descent who sojourned through Turkey, Edessa (Mesopotamia), Israel, and Syria into India ca. 345 AD, settling between the Sahyadri Mountains and the Arabian Sea. Known also as Kanahi (Kanai or Kanaa'im) Aaronites, this endogamous Jewish-Keralite clan derived from the Southern Kingdom of Judah, which was, purportedly, among the fourth sect of the first-century rebel movement after Rome declared Judæa as its own province and altered its name to Syria Palæstina. The Qnai Christians exist now under the direction of the diocese of the Syriac Oriental Orthodox Church led by the patriarch of Antioch and the Syro-Malabar Catholic Church. ${ }^{22}$ Because they clung to their vestigial Mosaic minhagim (traditions and customs) and maintained observance of ancient Hebraisms, these Christian Jews came under persecution by the Portuguese during the Goa Inquisition (1560$1812 \mathrm{CE}$ ) and were among the many thousands executed by Tippu Sultan in the late 1700 s. $^{23}$

Also of the Judæo-Nazaræan diaspora are the Suriyani Christians (Syrian Malabar Nasranis), Jewish converts observing the Syriac liturgy whose forebears were of the Northern Kingdom. They preceded the Kanahi, having first arrived in Kerala from Samaria after Babylonian deportation ca. 573 BCE. This ethnoreligious group, known locally as Nasrani Mapillas, are now members of the Syro-Malabar Catholic Church (Syro-Chaldæan Church), adhering to the Assyro-Chaldæan/East Syrian Rite.

Among decimated documents of the Jewish Christians of Malabar were the unadulterated texts of the original Syrian Aramaic Old Testament and Peshitta (Bible of the Church of the East), brought to India in the fourth century BCE prior to their Greek and Latin translations. The Old and New Testament manuscripts along with the entire library encompassing their Qurbana liturgy in the Malayalam language were burnt into oblivion by the Portuguese, with the exception of one solitary copy remaining hidden in the remote mountains. There are many listings from Christian Indian printers within the VTL collection, but I was unable to discern Qnai or Nasrani leads.

22. Archeparchial Curia, "History of the Archeparchy of Kottayam," The Archeparchy of Kottayam. Available online at www.kottayamad.org/decrees.htm. [Accessed 26 September 2009].

23. J.B. Brain, Christian Indians in Natal 1860-1911: an Historical and Statistical Study (Cape Town: Oxford University Press, 1983), 167-78. 
Among the Temanim, Habbani (a warrior tribe said to be descendants of the Judean soldiers commissioned by King Herod, from whom Jordan's King Abdullah I selected his Sofer family retinue of bodyguards), Hadhrami, ${ }^{24}$ and Sharabim of Yemen (Eudaimon Arabia) who formed coalition with the Bene Israel are those Jews who relocated to Hyderabad, Malaya, Singapore, and the Dutch East Indies (Indonesia). These southwest Asian remnants are the progeny of the Tribes of Dan, Zebulun, Asher, and Napthali who arrived as a squadron (along with a contingent of Kohanim and attendant Levites) in the domain of the Sabæan Kingdom ${ }^{25}$ (as distinguished from the warrior tribes who were dispersed to Khorasan). Correspondence between Maimonides and the Yemenite scholar Jacob ben Nathanael in 1172 resulted in the response-Iggeret Teman (Epistle to Yemen)—after Maimonides' brother David drowned somewhere in waters between the Red Sea port of Aydhab in Nubia (northern Sudan) and the Indian Ocean after embarking on a commercial voyage to India.

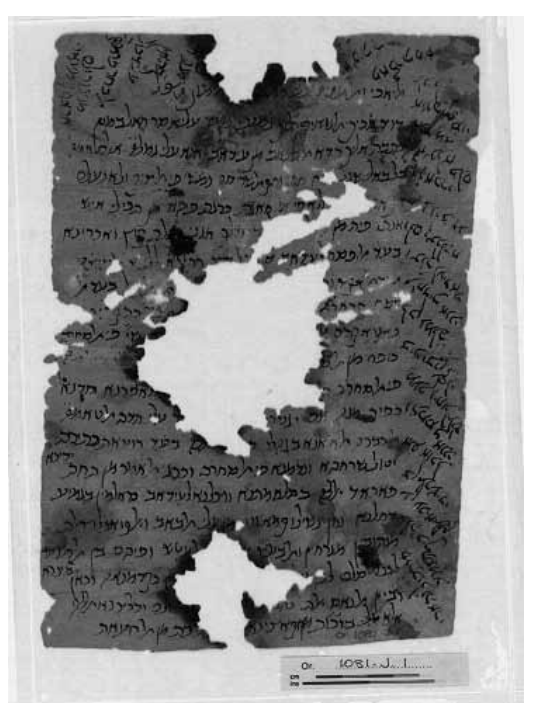

Image 9. Last letter received by Moses Maimonides from his brother David, prior to David's deadly Indian sea voyage, ca. 1170 CE. Cambridge University Library, Or. $1081 \mathrm{~J} 1$. With permission of the Syndics of Cambridge University Library and the Taylor-Schechter Genizah Research Unit.
Yemenite texts penned before the ninth century $\mathrm{CE}$ are scarce and veiled, but the years between 1150-1500 CE were scholastically productive in the realms of maqamat (melodies) and liturgical poetry, commentary, midrashic compilations, halakha, philosophy, lexicography, and science. Noteworthy Yemenite scribal families and poets (al-Shabezzi, ben Saadiah, al-Dhahrari, Sirri,al-Adani, ben Margaz) penned superlative works in Hebrew.

Rabbi Yihhyah Qaffah preserved manuscripts of Maimonides and his grandson published these via Israel. Seventeenthcentury CE Malabari Jews imported their Torah scrolls and books of law from Yemen and a Malayalam maqamat tracing exilees expelled by Shalmaneser V is still sung among Malabari Jews who chant the

Song of Everayi, a Judxan who arrived by way of Yemen, dwelling first among the Brahmin of Palayur before moving on to Chennamangalam.

24. Ausubel, Pictorial History of the Jewish People, 220.

25. James Hornell, "Naval Activity in the Days of Solomon and Ramses III," Antiquity 21 (1947): $66-73$. 
The only Hebrew printing press that existed in 1800s Yemen was among the Adani, who were avid bibliophiles; compositions of Yemenite Jewish authors were initially products of Indian presswork. VTL owns much material produced by the Aden pressroom and holds leaves of the Kinot according to the Aden Rite. A fine feature of Oriental Jewish scribal art was shown in the Manuscripts Room in the form of a 1490 century Yemenite Pentateuch written in Temani Hebrew script, embellished with Orientalist motifs.

As a result of the Al-Hambra decree of 1492, Sephardim of Spain who were driven from their aljamas (Jewish quarters) sought shelter in Portugal, whence they were subsequently also forcibly discharged. Many made their way to Goa, Surat, Bombay, Gloconda, and settled in Madras where they merged with transplanted Caribbean and South American Jews of Barbados, Jamaica, Nevis, and Suriname (formerly Dutch Guiana).

\section{Crypto-Judaism was practiced by} those remaining who, under duress, felt compelled to convert publicly for sake of survival while maintaining their religion privately. Those who remained in Spain and Portugal are deemed

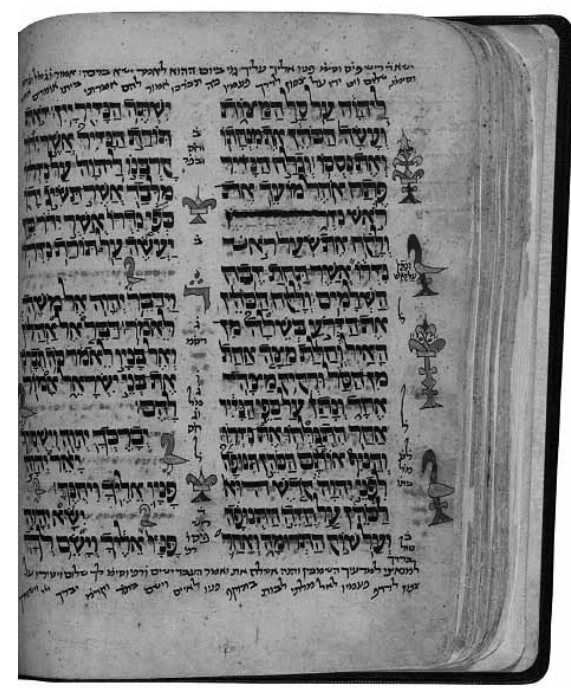

Image 10. The Pentateuch, Yemen, early fifteenth century CE manuscript. Oriental Hebrew illuminated manuscript embellished with motifs and masoretic notes on pronunciation and intonation, Valmadonna Trust Library. Courtesy of Sotheby's.

\section{Cristãos Novos, Marranos, Chuetas,}

and Anusim. ${ }^{26}$ Centuries later, some from the Sephardi strand journeyed from the Iberian Peninsula into the Maghreb and Ottoman Empire; others ventured to the Netherlands (formerly part of the Spanish Empire). As a result of the Shoah (Holocaust), the original Sephardic community of the Hague met its demise. Along the cosmopolitan continuum, they are now ensconced within the Paradesi/Cochini community in Kerala and are known as Juda Mappilas.

Supreme among the Sephardim incunabula at Sotheby's was a rare copy of a 1490 Hijar Pentateuch printed in Spain (featuring Hebrew and Aramaic fonts printed on vellum) from the provenance of the David Solomon Sassoon Library in Bombay (now Mumbai). Other superlative finds among the Sephardic lot are a substantive number of works by kabbalist Manoel Dias Sœiro (Manasseh ben Israel) and a 
Marathi translation of the eleventh-century Azharot (Exhortations) compositions by renowned Andalucian poet/philosopher, Shlomo ibn Gabriol.

The Sindh and neighbouring provinces of Pakistan are the historic home of the Yehudi of the Punjabs. These Bnai Yisrael and Baghdadi branches ${ }^{27}$ migrated from Bombay to Quetta (southern Pakistan) to the seaport of Karachi and onward to Peshawar, where also the bordering Bukharan of Afghanistan were joined by Pathans (Benjamin Tribe of the Hindu Kush Mountains) ${ }^{28}$ and Jews of Khiva (Uzbekistan) and Khorasa to create communal lives in the Northwest Frontier Province. In a differently directed demographic oscillation, some Pakistani Jews emigrated to India with the concurrence of India's independence from Britain in 1947, Pakistan's nascent nationhood as an Islamic state in the same year, and the confluence of the creation of the Israeli state that resulted in post-partition pogroms of Pakistani Jews, their large-scale migration over India's newly drawn border, then northeastward into China. Observing Sephardic rites in the mother tongue of Marathi, the Pakistani Jews are collectively included under the umbrella term Mizrahim (Edot Ha-Mizrach, Communities of the East) for Oriental Jews. Persian Jews ${ }^{29}$ (including those known as "New Moslems" or "Jedid-al-Islam" who underwent forced conversions) used secret escape passages via southeastern desert channels of Iran that connected Jews of Arabia through Pakistan into India.

Commonly shared literary languages of these peoples are Punjabi, Urdu, Sindhi, English, Pashtu, and Balochi. The first printed book in Urdu was released in early seventeenth century CE; and, by the nineteenth century, a well-established Pakistani publication industry disseminated many works of translations. The principal print centres are in Karachi, Lahore, and Peshawar. During my visit to Sotheby's, it was my ethereal pleasure to behold a lithograph of a classical Hindustani operaIndar Sabha (Court of Indra) - in Urdu transcribed with Oriental Hebrew script.

To the mesh of Yehudim, whose sixth-century BCE Eurasian sojourn ended in Azerbaijan and Iran (known collectively as Persian Jews), were added the transplanted Armenian, Turkic, Georgian, ${ }^{30}$ and Iraqi Jews who inhabited Isfahan, Susa, Tehran, and Shiraz. Of these Mizrahim are the split branches of the Central Asian Bukharan and The Mountain Jews of Daghestan ${ }^{31}$ (Yehudim Harariyim, Judæo-Tats), in addition to those who faced forced fifth- and seventh-century CE Islamic and Bahai conversions or expulsions. Ancestors of the Mountain Jews (set-

27. Joan G. Roland, "The Baghdadi Jews," in The Jews of India: a Story of Three Communities, eds. Orpah Slapak and Muzeon Yisrael (Jerusalem: University Press of New England, 1995), 37-43.

28. Ausubel, Pictorial History of the Jewish People, 221.

29. Ibid., 218-19.

30. Ibid., 220.

31. Ibid., 221. 
tlers of what was designated inter se as "the Second Jerusalem") are believed to have been the Persian Jewish infantry station in the Caucasus serving under Sassanid rulership (226-652 CE). Among this amalgamation were Jews of Afghanistan, Tajikistan, Turkmenistan, Kirgistan, Uzbekistan, northern Pakistan, northwestern India, and the Jewish Mughal Courtiers of India. The Sons of Joseph (Yusufzai) are domiciled here also in this Northwest Frontier Province of Pakistan-kin to the Mountain Jews and as fiercely intrepid. Comprised within the Baghdadi Jewry, the Persian Jews resided for centuries in Bombay, the Rann Kutch region of northwest India, the Sindh province of southern Pakistan, and Xinjiang in western China.

Works representative of this region at the Sotheby's exposition were The Book of One Thousand and One Nights (Arabian Nights) in Judæo-Arabic, an edition of Passover Haggadah with Judæo-Persian translation according to the Persian Rite. I searched unsuccessfully for quatrains of Sarmad (the mystical Jewish Persian poet of India who produced a translation of Torah in Persian), a Hebrew translation of a Sephardic prayerbook (printed in Vilna, Russia), and for a listing of Hed Harim, the Soviet era Judæo-Tat newspaper read by the Mountain Jews.

Another segment of Samarian Jews, referred to above, were directly deported to Armenia by the Assyrian King, Sargon II. Later, when Tigranes the Great retreated from Palestine, thousands of Jews returned with him to Armenia in the first century BCE. The Persians later deported these rootless cosmopolites from Armenia, resettling them in Isfahan (Iran) where they were ultimately subsumed into the Persian Jewish collective. By the seventh century CE, Armenian Jews integrated into settlements along the Malabar Coast, later venturing throughout India, Pakistan, Bangladesh, and Burma.

Dislocated Ashkenazim (Yehudei Ashkenaz) find their omphalos in the medieval Rhineland of Germany and Northern France. ${ }^{32}$ Observing Rabbinic Judaism and Babylonian Talmudic culture, they were expelled from Gaul in $629 \mathrm{CE}$, later banned from some French regions, buried in an open pit in another. Those Ashkenazim migrating eastward to escape between the tenth and nineteenth centuries CE did not form a separate segment within the Indo-Judaic community once they arrived. When the German Nazis implemented their "Final Solution" expulsion plan, some German Jewish refugees escaping the Shoah (Holocaust) sought refuge in Bombay en route to China, Sri Lanka, Phillipines, and Japan. Under auspices of the Imperial British Raj and their well-ensconced Indo-Hebrew hosts, Ashkenazim lived as exiles in India between the years 1933 and 1945. Visas were to be obtained for Calcutta, Madras, and Bombay, but many of these formerly affluent, newly dispossessed, fled without capital, being disallowed to make German capital transfers.

32. Gilbert and Banks, Jewish History Atlas, 26. 
Penniless, some were allowed to land, but others were redirected, prohibited from disembarking. VTL is in possession of a few titles that affirm Indo-Ashkenazic immigrant connections, including a Madras printing of a travel memoir (The Travels from Jerusalem, through Arabia, Koordistan, Part of Persia, and India (1824-1832) by David D’beth Hillel (a native of Lithuania) with glossary of Hebrew, Arabic, Persian, Hindustani, and English vocabularies.

Sri Lankan Jews of Old Ceylon ${ }^{33}$ had a presence in South Asia, as recorded by medieval-era Sephardi explorer Benjamin of Tudela, until World War II. VTL denotes among its listings Tudela’s Masa'ot shel Rabi Binyamin, which enumerates his encounters with Jews of Ceylon and his other Asian adventures. A press with movable Sinhala type was established in Ceylon in 1736 in a joint venture by the Dutch Christian establishment and the Dutch East India Company; VTL's copy is an 1866 product of a Baghdad, Iraqi printer trained in India.

Burmese Judaism ${ }^{34}$ was an outcome of the nineteenth-century trek of Bene Israel/ Cochinim/Baghdadi following the trail of prosperity toward Southeast Asia and the Pacific. From Calcutta to Rangoon (Yangon, former capital of Burma) and

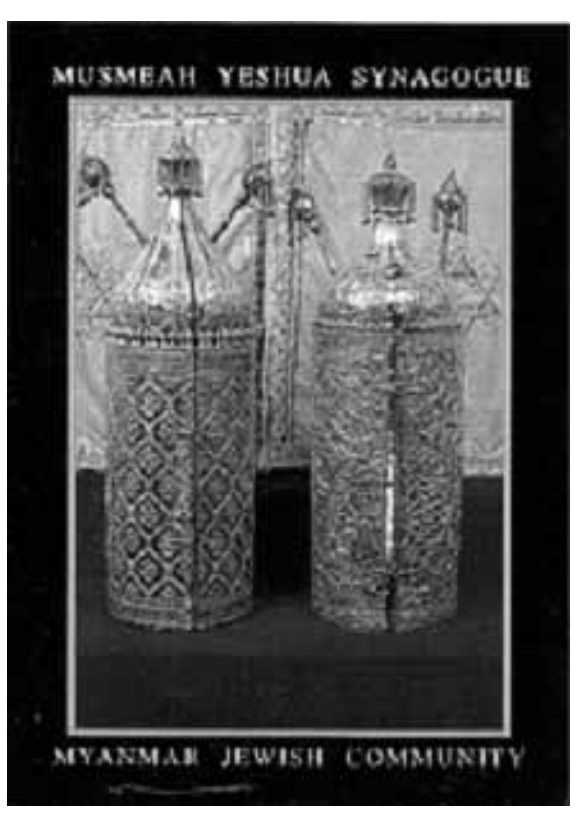

Image 11. Sefrei Torah of the Musmeah Yeshua Synagogue, Burma. Image source: Stephanie Comfort. Used with permission.
Mandalay, onward to Singapore, Jakarta, Bangkok, Saigon, Manila, Tokyo, Hong Kong, Shanghai, Maymo, Moulmein, Bassein, Akyab, and Toungyi, they increased their wealth and presence. Burma's (Myanmar) Musmeah Yeshua Synagogue once held 126 Sefrei Torah; only two remain.

Stone fragments were found near Luoyang province-written in a Palmyrenean Hebrew script derived from Aramaic - attesting to a Syrian Jewish population during the Eastern Han Dynasty (25-220 CE). ${ }^{35}$ From these tablets, scholars adduce that Jewish merchants of Syria, which had a tributary relationship with China,

\section{Ibid., 12.}

34. Nathan Katz and Ellen S. Goldberg, "The Last Jews in India and Burma," Jerusalem Center for Public Affairs. Available online at www.jcpa.org/j1/j1101.htm. [Accessed 8 September 2009].

35. Sidney Shapiro, Jews in Old China: Studies by Chinese Scholars (New York: Hippocrene, 2001), 57-59, 193. 
held a settled, solid presence in the region. The medieval-era Jewish guild of the Radhanites $^{36}$ (from the Persian phrase meaning "knowing the way") traversed Eurasia (ca. 500s to $1000 \mathrm{CE}$ ), expanding a massive mercantile network that commenced in the Rhône Valley of France (Firanja) and terminated in China. Trekking spices and Saqaliba slaves, jewelry, perfumes and incense, harem girls and eunuch boys, silks and beaver skins, servants and swords and soldiers of fortune, furs, musk oil and opium, aloes, camphor and cinnamon, mercenaries and medicines over land and by sea through France, Egypt, Syria, Saudi Arabia, Oman, Iraq, Turkey, and Persia, the Radhanim made their way through India, Pakistan, Afghanistan, Balkh, Khotan, Samarkand, Tashkent, Khiva, Uzbekistan,Khamlij, Khazaria, Transoxania, Bukhara, and onward into Chinese Turkestan. By ca. 800 CE, Persian Mizrahim engaged with the Radhanites (functioning as liaisons between the Occident and the Orient, the Kingdom of the Franks, the Old Roman Empire, and the Tang Dynasty employing languages of Old French, Arabic, Latin, Farsi, Byzantine Greek, Spanish, and Slavonic as bridges) to establish an "Emporium of the East," a transcontinental trade post in the ancient port city of Daybul (Sindh province, formerly NW India). By the years 200 and $1000 \mathrm{CE}$, China was considered to be-for many Jewish Turkestan traders and Persian refugees-home, where they stayed and settled. Bearers of more than merely bulk merchandise, the Radhanim (Radhaniyya) also conveyed products of the Asian mind from East to West. The merchant/mathematician Joseph of Spain is credited by the astronomer Avraham ben David ha-Levi with transmitting the elegantly ethereal Hindu numerical concept of "zero" to Europe via the Arabs. ${ }^{37}$ A Persian business letter written in Hebrew script on Chinese or Persian paper (dating back to $708 \mathrm{CE}$ ) was discovered in the Xinjiang province (bordering Tibet and India). Radhanites were consumers of a carbon ink known as masi (utilized in India and China since the fourth century BCE) and paper (varieties of which were developed during the Eastern Han, Tang, and Song Dynasties) on which to write commercial contracts, inventory lists, and with which to wrap delicate goods. Their interactions in China, the Middle East, and Andalusia laid the early groundwork for the future establishment of Arab paper mills in Spain and, ultimately, the development of print production and furtherance of knowledge transmission.

Within the Caves of a Thousand Buddhas (Mogao Grottoes) in Dunhuang was discovered a page of Sehilot (penitential prayers) written in Hebrew on paper, dated to ca. eighth and ninth century CE, ${ }^{38}$ a possible link to those known as Kaifeng Fu $\mathrm{Jews}^{39}$ who are the Youtairen who travelled from Persia to China during the Han dynasty (206 BCE-220 CE), later emigrating from Gansu Sheng province to Henan

36. Gilbert and Banks, Jewish History Atlas, 12, 22.

37. Charles Seife, Zero: The Biography of a Dangerous Idea (New York: Penguin Group, 2000), 58-81.

38. Shapiro, Jews in Old China, 60.

39. Ibid., 23; Ausubel, Pictorial History of the Jewish People, 223. 


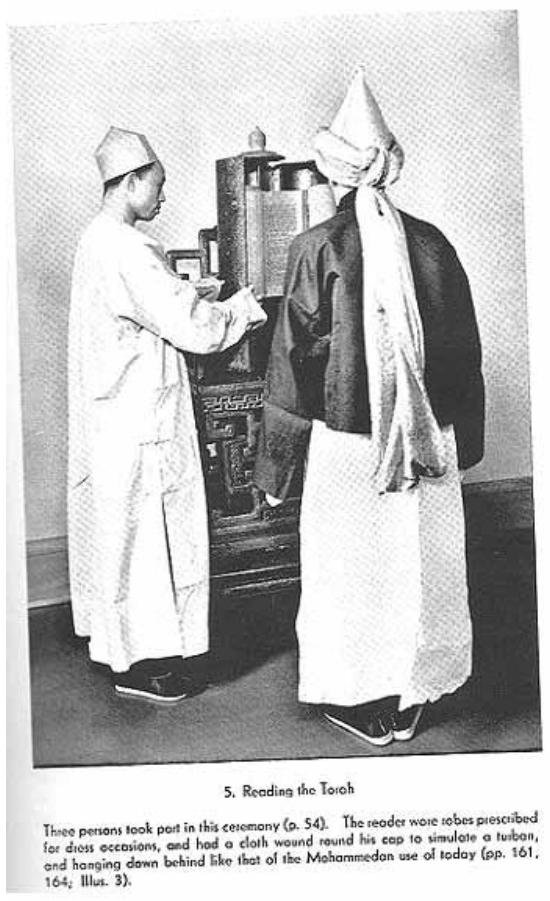

Image 12. Reading of the Torah by Kaifeng Jews. Image source: Wikimedia.
Sheng province during the Northern Song dynasty (960-1127 CE), residing in regions of Bianjing and Hangzhou during the Yuan Dynasty (1271-1368). From 1000 CE to 1932, Sino-Judaic communities ${ }^{40}$ were established in towns of Tun-huang, Lanchow, Tungming, Kaifeng, Hangzhou, Changpu, Ningpo, Canton, Shanghai, Harbin, Tianjin, Hong Kong, and elsewhere. Maritime sailors of the Oriental diaspora travelled to China on Arab, Persian, and Chinese vessels between the Tang and Southern Song Dynasties (seventh to thirteenth centuries $\mathrm{CE})$. Jewish soldiers who served were bestowed settlement lands by Emperor Taizu.

During the Yuan dynasty, permanent Youtairen villages existed on the Southeast Asian coast. Indian Jews

and independent European Jewry made China and Japan their new domicile in the 1800s. The Russian Revolution, the Russo-Manchurian Treaty, the Russo-Japanese War, Nazism, and the Trans-Siberian Railway were the concomitances impelling massive movements of Jews into China and Japan; but the Shoah, World Wars I and II, the Sino-Japanese Wars, Shanghai ghetto subjugation, Lunghwa concentration camp oppression, and Mao all determined that Manchuria was not to be their final mooring.

Kaifeng Jews divided the Torah according to Persian specifications. ${ }^{41}$ They possessed three Sifrei Torah in the 1400s. During the Chen Hua period (1465-1488), a Torah repository was constructed and by the 1500s-1600s, its inventory increased to thirteen scrolls. A 1642 flood caused damage, but restoration efforts redeemed these: twenty-six Scriptures, miscellaneous writings (in Judæo-Persian) written on parchment including religious laws, doctrines, rites, recitations of Purim (festival commemorating deliverance from Persian annihilation plot), a seventeenth-century CE calendar scroll calculated according to second-century CE methods, and more. ${ }^{42}$

\footnotetext{
40. Gilbert and Banks, Jewish History Atlas, 22.

41. Shapiro, Jews in Old China, 43.

42. Ibid., 43-45.
} 


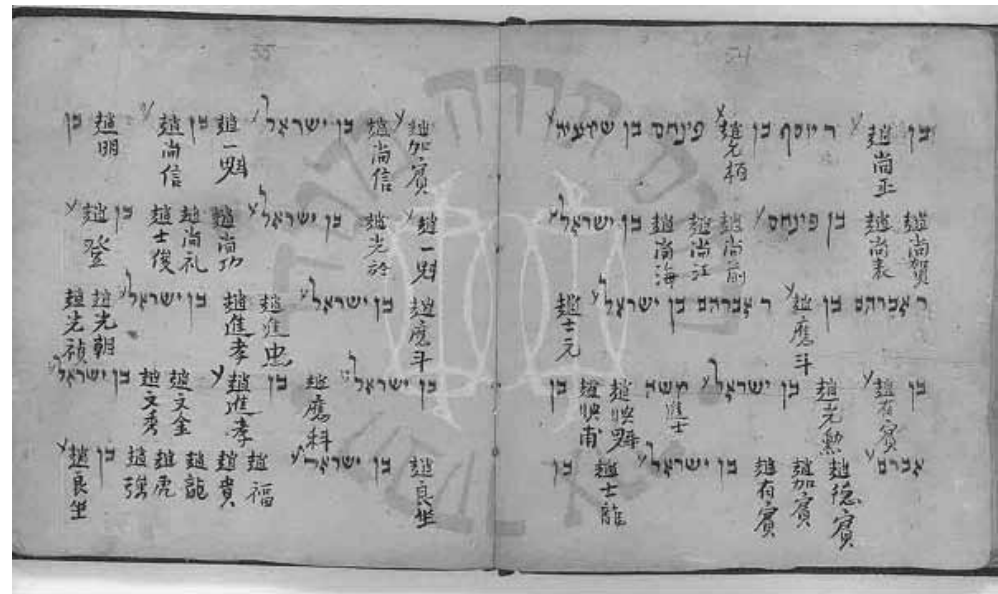

Image 13. Kaifeng Congregation Prayer Book \& Members List, Ming Dynasty. HUC Ms 926. Image source: Hebrew Union College-Jewish Institute of Religion, Klau Library, Cincinnati. Used with permission.

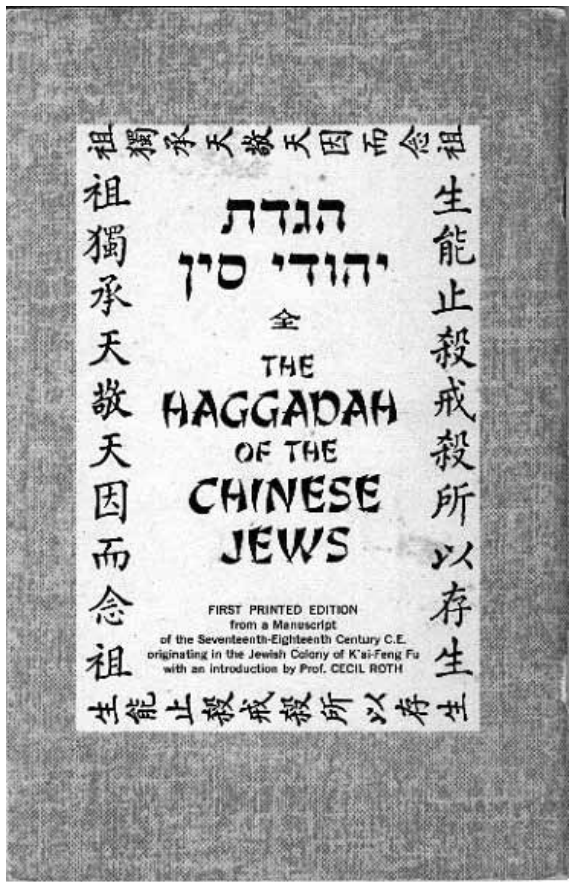

Image 14. The Haggadah of the Chinese Jews. First printed edition from seventeenth century CE manuscript. Image source: Judah L. Magnes Museum. Creative Commons License 3.0.
Difficulties of early Chinese typography involved the requirement of more than 100,000 ancient characters and hieroglyphic symbols to execute standardized, legible text. The running, calligraphic typescript style of the written word in Chinese, Japanese, and Arabic posed problems in earliest printing press attempts. Woodblock printing was not as suitable in Europe as in Asia, where alignment of characters was not as critical. Use of the Latin alphabet required precision and simplicity. Innovations advanced by Gutenberg ${ }^{43}$ and others in Netherlands, France, Germany; limitations of Asian typesetting; and selection of the Rashi script as the industry standard impelled the proliferation of Hebrew-language printing and the notable presence of Jews in Sino-Judaic publishing.

43. Thomas Christensen, "Gutenberg and the Koreans." Available online at www.rightreading.com/ printing/gutenberg.asia/gutenberg-asia-1-introduction.htm. [Accessed 8 September 2009]. 


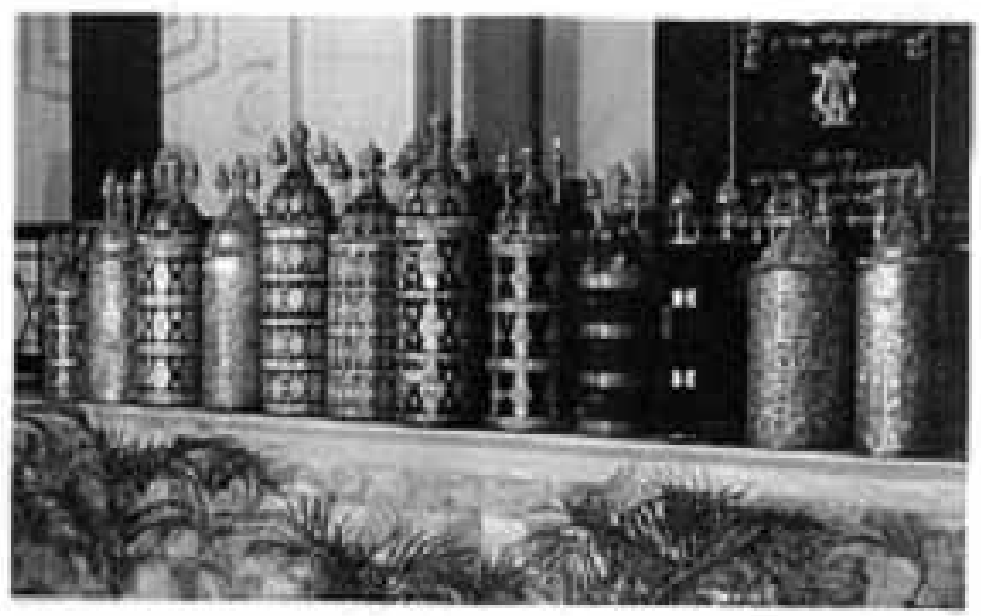

Image 15. Torah Scrolls, Hong Kong Synagogue. Image source: Stephanie Comfort. Used with permission.

Some of the numerous, multilingual Chinese Jewish publications were Evreiskaia Zhizn (Jewish Life), Der Vayter Mizrekh (The Far East), Gadegel, Our Life, Jewish Chronicle, and Jewish Voice of the Far East (Juedisches Nachrichtenslatt). Inclusive within VTL's Chinese cache are imprints of the Zionist newspaper Israel's Messenger, an Ohel Rachel Synagogue Order of Service: Seder ha-Tefilot Book of Prayer and Order of Service According to the Custom of the Sephardic Jewish Community, Siddur Kol Benei Yehudah, and Pizmonim le-Simhat Torah—all of which are Shanghai selections.

VTL's Middle Eastern and Asian holdings are works of the creative, consecrated labor of the many. Regrettably, every single private publisher, independent job house, scribe, copyist, and master printer could not be compiled here, but this list still merits compilation.

Calcutta: Newman \& Co. Ltd. Publishing \& Distribution Centre, Shelomoh Tvena, Essco Press, Iraki ha-Kohen, Ganguli, Be-Litografiyah, Eastern Press, Einy Press, Kuntaline Press, India Press

Bombay: English and Vernacular Printing Press, Anglo-Jewish and Vernacular Press, Hebrew \& English Press, Bahadur Printing Works, Lebanon Press, Vaibhav Press, Ganpat Krishnaji Press, Rebekah Simeon Walker Printing Press, Israeli Granthamala, Nirnaya-sagar Press, Sutya Prukash Press, Majagamva Printing, Oriental Press, Tatva Vivechaka Press, Lebanon Type \& Litho Works, Sri Lakshmi-Narayana Press, Fort Printing Press, Bombay Hebrew Publishing \& Printing Press, Industrial Press, Esa Ramana Pressa, Asiatic Printing Press, So. En. Presa/Giragmva, Solomon Moses, Purandare Company Printing Press, Aaron Jacob Divekar, Bene- 
Israel Improvement Society, Dhi Serasvati Printing Press, Ezekiel Shemtobe David's Press, Friends' Printery, Bombay Tract $\&$ Book Society, Ramakrsna Printing Press, National Information \& Publications Ltd. Press, Ganpat Crishnaji Press, Arunodaya Press, Satyavakta, Education Society's Press, British India Press, We-One Printers, Karani Art Printing Press, Israelite Society Printing Press, Ubelinda Printing Press, New Amberkar Printing Press, Alankar Printers, Sawant's Print-Bind-Read Service, Jewish Sanmarga Darshak Samaj, Mebasser Printing Works, BES Press, American Mission Press, Manoranjam Press

Israel: Friedman's Printing Press, Oth Cooperative Printing Press, Misgav Yerushalayim, JP Printing Press

Poona: Orphanage Press, Ambaprasada Chapakhanyanta Chapile, Ananda Mudranalaya, W.W. Atitkar, A. D. Ezekiel Press, Hindustan Sahitya, Vital Skharam Agnihorty's Press

Kerala: Thilakam Press, Sathiaprakashni Press, Yefeh Nof

Baghdad: Elisha Shohet, Yosef Hayim Menasheh, Dangoor, El Wataniyah Israiliyah

Bangalore: Mahamadana Printing Press

Karachi: Induprakasa Stima Press, Karnatak Press, Maratha Press, Royal Printing Press

Delhi: Atlanta Offest and Packaging Ltd, Vikas Publishing House

Shanghai: de Souza

Madras: Madras Publishing House

Iran: Kalimian Press ${ }^{44}$

Genizahs (hiding places) are where worn, damaged Hebrew-language writings, and sacred scriptures in languages other than Hebrew or Greek, are placed to die before burial in a synagogue or cemetery. Sanctity of process and purity of intent in the writing of all living books — even nonsacred documents—are governed by specifications of the Pentateuch. Distinctions for respectful disposal by burning or burial,

44. Brad Sabin Hill, "Hebrew and Judeo-Arabic Printing in Baghdad" (Leiden, Netherlands: IDC Publishers), available online at www.idc.nl/?id=371 [accessed 8 September 2009]; Brad Sabin Hill, "Hebrew, Judeo-Arabic, and Marathi Jewish Printing in India" (Leiden, Netherlands: IDC Publishers), available online at www.idc.nl/?id=521 [accessed 8 September 2009]. 
for works by Gentiles, and Jewish heretics, and even the honorable ending of lives of mechanized texts brought into being by technology are delineated in accordance with the discernment of rabbinical guidance and authority. Jack V. Lunzer-passionate protector, obsessive preserver, devoted Custodian—has, via his lifelong Valmadonna "rescue operation," spared so many worthy works from the solemnized genizah gathering of their old, aging content in mourning rituals of literary loss. He has rendered them fit for many centuries more of scholastic education and personal edification, for Jews and non-Jews alike. Yet, the final disposition of this splendid treasury — as of the date of this writing —is still unknown. No finalized sale has been announced by Sotheby's. No major research institution has come forth to newly claim the trove. No university declarative communiqué has been issued.

Although much desired by the United States Library of Congress ${ }^{45}$ (with an earmarked account set-aside several years ago specifically for the eventual acquisition $)^{46}$ the leather-bound beauties of the Valmadonna Trust Library are beyond its means. Where the words and illustrations of this endlessly grieving, everlastingly grand, collective human experience will carry on their futures; on whose silent mahogany shelves they will now find expression is momentarily shrouded, their access temporarily denied, their new lives under negotiation.

45. Katya Kazakina, "Rare Jewish Bibles, Talmud May Fetch $\$ 40$ Million at Sotheby’s," Bloomberg. Available online at www.bloomberg.com/apps/news?pid=20601088\&refer=home\&sid=a084B5FRM1 PY. [Accessed 8 September 2009].

46. Richard and Rhoda Goldman Fund, Charitable Funds 2000 Annual Report (San Francisco: Richard and Rhoda Goldman Fund, 2000). Available online at www.goldmanfund.org/pdf/2000_annual-report. pdf. [Accessed 8 September 2009].

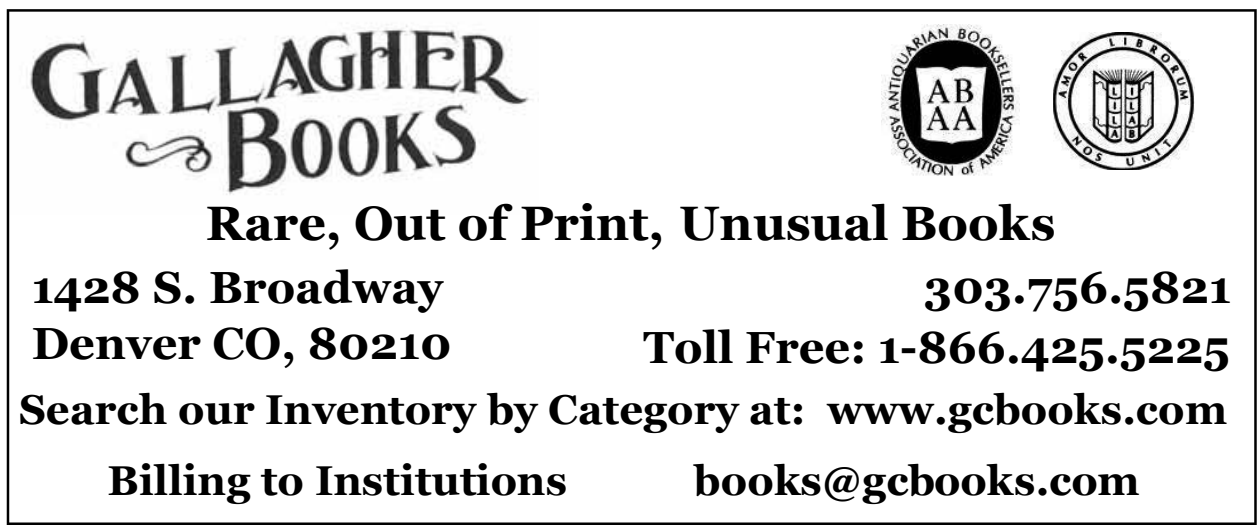

